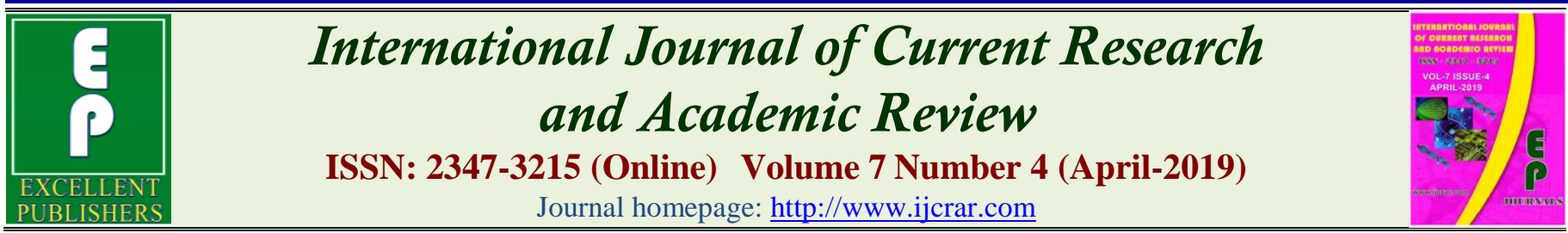

doi: https://doi.org/10.20546/ijcrar.2019.704.005

\title{
An Assessment on the Implementation of Process Approach in Teaching Writing Skills: The Case of Preparatory Schools in Wolaita Zone
}

\author{
Mesfin Mekuria Dangore*
}

Department of English Language and Literature, Wolaita Sodo University, Ethiopia

*Corresponding author

\begin{abstract}
It is obvious that the English courses offered in different schools are based on the assumption that what is taught and learned in these schools would help students overcome their previous writing problems and write well in their English. The major objective of this study was to assess the implementation of process approach in teaching' writing skills and to identify kinds of errors the students commit during writing through process approach. To this end, checklists were prepared so as to check the students' writing skills. Textbook content analysis, teachers' and students' questionnaire results, semi-structured interview with teachers and students, and classroom observation results were used. Subjects selected were Wolaita Sodo preparatory school grade 12 students and teachers. Using purposive sampling technique, ten (10) English teachers of grade 12 were included as a sample for this study because they were fewer in number and easily managed. Out of 1200 Grade- 12 students, 300 sample students were taken using top 20 achieving students from 15 sections (section A-to-O) for filling the questionnaire. In relation to this kind of subject selection technique, Mertler (2005) recommends that about $20-25 \%$ of the respondents should be selected from the total population. According to his recommendation, this study included $25 \%$ of the total population as the student respondents of this work. Concerning the research design, a descriptive research design was used to analyze and interpret the data. The findings of the study indicated that the students' writing skill is terribly low. Tests were given to the participants and it was found that students couldn't keep the given good paragraph writing criteria. In effect, students wrote fragmented ideas without giving a complete idea and they were generally found less successful in meeting the writing requirements and expectations of the teachers, specifically; teachers' expectations in terms of writing skills and English language proficiency because most of the students scored below an average value and also the higher value lied in negative standard deviation and mean. Moreover, both teachers and the students appeared to have different views as to the responsibility of teachers to help students improve their writing skills. However, as a whole, it was found out that the teachers in the Wolaita Sodo Preparatory school appeared to have paid little attention to help their students improve their writing skills though it is possible that some teachers may individually help their students. My observation in the real classroom practice also indicated that some students even couldn't write a single meaningful sentence let alone writing effective paragraph in the grounds that the teachers and students of grade 12 were not practicing writing skills using process approach. Some factors which hinder the implementation of process approach reported by both teachers and students were shortage of time, low background knowledge in writing, and interest, inappropriate contents and lack of support. By and large, the students written test score performance was very poor; students learn writing in rare cases, which resulted students to be passive in learning writing skills except few students who were found voluntary and motivated while about $225(75 \%)$, out of the total students, were not ok. Students' motivation to write outside the class was also reported to be low. According to the students' text book analysis, it was reported that writing exercises found in grade-12 textbooks were not authentic, and as a result, do not show various steps to develop the students' writing skills, but similar activities were presented in each unit though students at this level must see various forms of academic writings. Therefore, the researcher likes to recommend that students should be given very practical process writing tasks from the very beginning so that they can be able to develop their writing skills step by step, and writing tasks should be given individually in order to minimize the dependence on a single student.
\end{abstract}

\section{Article Info}

Accepted: 04 March 2019

Available Online: 20 April 2019

\section{Keywords}

Assessment, Implementation of Process Approach, Teaching Writing Skills, Preparatory Schools 


\section{Introduction}

It is obvious that the English courses offered in different schools across countries are based on the assumption that what is taught and learned in these schools would help students overcome their previous writing problems and write well in their English (Kefelegn, 2003). Scholars in the area also argued that failure to meet academic expectations for EFL or ESL students in writing at advanced level lie in factors such as lack of previous training in writing and L2 difficulty (Bizzell, 1982); constraints imposed by the writing tasks (Zamel, 1983); lack of writing tasks awareness (Flower et al., 1990), and cultural barriers in writing (Connor, 1996). In the way to design strategies to improve the students' writing, recently introduced 1970's communicative language teaching (CLT) approach gives equal chance for all language skills- both micro and macro skills, but most students, according to Connor, 1996, give priority for micro skills, especially for grammar. Next to this, students like working on reading and vocabulary sections. Of all skills in English, writing is considered to be the most complex and difficult skill to master due to reasons mentioned above by scholars. This difficulty, according to Richards and Renandya (2002:303), also lies not only in generating and organizing ideas but also in translating these ideas into readable texts.

In most parts of the world, English is used as a means or medium of communication among a wide range of people. Of course, communication through effective use of language skills is the recent main objective in teaching English that the Communicative Approach requires. Writing is also done for communicating messages and reinforcing other language skills.

Pincas (1982:45), on his part, states that writing (composing) is a process which involves arrangement of ideas into sentences, organization of those sentences into paragraphs and then construction of whole essays, stories...etc, and in this regard, a process approach to writing pays attention to the various steps that any piece of writing goes through, as it is argued by Pincas. By spending time with learners on pre-writing phases, editing, re-drafting and finally publishing the work, the process approach aims to get the heart of various skills that should be employed when writing (Harmer, 2001: 257-258).

In spite of the need for conducting such research, to date, several of the local studies conducted in relation to writing, including Abebe (2003) who conducted a research on "Awareness of Subject Area Instructors about their Contributions to the Development of Students' Writing Skills" and Teshale (2009) "The Relation between Teachers and Students Perception of Writing Skills and Students Academic Achievement", have mainly focused on problems related to the teachers' and students perception and attitude on writing at the University level, but they didn't see the application of process approach in focus. Even though lower school levels are found to be the baseline for the next college and university levels, not much attention has been given to preparatory schools. When the students join university, they are still unable to write an effective sentence or paragraph due to poor primary school background. As a result, most of English teachers face problems with students' writing skills. So, this initiated the researchers to conduct this study in Wolaita Zone preparatory schools to assess the implementation of process approach in teaching writing skills.

\section{Statement of the Problem}

As many scholars in the area of writing argue, the issue of writing theory development should conform to some basic components and the dynamic relationships among them (Jhons 1990; Ede 1992; Kroll 1990; Berlin 1982, 1987, 1988). These authorities also believe that all approaches to writing must consider the following basic elements: The writer, as a person who must discover something to convey; the reader, with whom the writer would like to communicate; the written discourse (text) that makes this communication possible; and the language, which can be influenced by or influences the other components. In the literature of writing theories, and teaching writing, these basic components have remained the organizing principles. However, English in Ethiopia is a foreign language, and students are not given due attention in teaching writing skills, but they learn the language as a subject and also use it as a medium of instruction for other subjects in high schools, colleges and universities. Thus, in order to make the students successful, the four language skills (speaking, reading, listening, and writing) have to be presented in a meaningful and integrated manner since communicative language teaching approach calls for a balanced presentation where by no means any skill is dominant over the others (Stern, 1983:28).

According to Stern, writing is a messy business. Most people progress through a number of untidy drafts before reaching a final version. Nor do they always follow what might seem a national order of priority; it is true that on 
the whole good writers think about content first and form later, but this order is not consistently observed. Actual content may be altered at quite later stages in the drafting, and changes into sentence or paragraph organization relatively early (Ur, 1996:168). Writing is also a process which uses purpose and audience framework for any choice of language, idea and organization.

The reasons for teaching writing to the students as a foreign language include reinforcement, language development; learning style and most importantly, writing as a skill on its own right (Harmer, 1991: 79). As a result, it needs giving attention on word selection, punctuation, spelling and grammar in order to write a unified and coherent paragraph or essay or any text. Unity, coherence, cohesion, and adequate development are also necessary because effective writing cannot be done in a short time; thus, it needs thinking more to transmit message to the audience. Moreover, learning to write is uniquely challenging, and requires the mastery and concurrent use of a complex array of English language skills, which is obviously difficult to SL writers. Due to this, every writer is suggested to pass through a number of successive steps before the final draft (planning, outlining, drafting and rewriting). In Wolaita zone, students usually take writing test without an adequate training and support on the task. Teachers expect very coherent, unified, edited and final camera ready paper without showing them ways to put words correctly into print. As a result, writing as a skill has been a bottle neck to majority, if not all, of students of preparatory schools in Wolaita zone, Ethiopia. Scholars, in this regard, claim that learners of writing should not be expected to bring accurate final written text to teachers. In these regard, different approaches for teaching have been presented. However, process approach doesn't need only the product or output but it needs the procedures that the writer passes through. It is a preferable approach than that of product approach (Nunan, 1998:142). This research is planned to assess the effectiveness of the implementation of process approach in writing skills and identify the factors that affect writing skills of Wolaita Zone preparatory School students. To this end, the researcher stated the following questions to be answered at the end of this study:

1. How do teachers and students in the schools apply process approach in teaching writing skill?

2. What are the major challenges involved in teaching and learning writing skill though process approach?
3. To what extent do the challenges affect the effectiveness of the approach?

\section{Objectives of the Study}

The primary aim of this study was to assess the implementation of process approach in writing skills.

The research specifically aimed at to:

1. Explore the implementation of process approach in teaching writing skills

2. Find out the challenges that affect the implementation of process approach in teaching writing skills.

3. Describe the magnitude of the challenges so that priorities can be set for immediate decisions

\section{Scope of the Study}

In this research, more specifically, students of grade-12 and English language teachers of Sodo Preparatory School were addressed. Teachers who were teaching other subjects were not included. Only grade 12 students were also focused because there are several sections to include other grade levels. It was also delimited only on effectiveness of implementing writing skill rather than listening, speaking and reading. For the sake of feasibility and manageability, the investigation was not extended than the specified boundary.

\section{Materials and Methods}

This chapter deals with research design, subjects of the study, sampling techniques, instruments employed during data collection, methods and procedures for data analysis.

\section{Research design}

Mixed research design (i.e. both qualitative and quantitative) was employed in order to conduct this study because it helped the researcher to have a valid data for the study or to gain a better, more substantial picture of the reality and to gain a more sophisticated understanding of the issue on the research questions and its objectives in a natural way (Denzin and Lincon, 2000).

\section{Participants of the study}

The study was conducted on government preparatory school in Wolaita Zone-Southern Nations, Nationalities 
and Peoples Republic (SNNPR). The school was selected purposively since the site enables the researcher to be in the school to make a thorough study. Preparatory school's EFL teachers and grade 12 students were the target population of this study.

\section{Sampling techniques}

Using purposive sampling technique, ten (10) English teachers of the grade 12 were included as a sample for this study because they were fewer in number and easily manageable. Out of 1200 Grade 12 students, the researcher selected 300 sample students using top 20 achieving students from 15 sections for filling the questionnaire. In relation to arguments forwarded concerning sampling techniques, Mertler (2005) recommends that $20-25 \%$ respondents should be selected from the total population. Based on this recommendation, this study included $25 \%$ of the total population as the student respondents of this work.

\section{Instruments for data collection}

In order to collect data for the study, the following data collecting instruments that were used to have significant inputs: Written test, Questionnaire, Observation and Textbook analysis.

To know whether the problem exists in the classroom, written-test was given to the students. The researcher prepared a topic with guided lists and gave them with separate sheets. It was more of guided. Next to this, the students were requested to write one unified and coherent paragraph using the outline. The researcher and assistants administered the test for 30 minutes. After the papers were collected, they were marked out of $20 \%$ with the criteria of unity-3\%, adequate development- $2 \%$, grammar-3\%, spelling-2\%, capitalization-2\%, coherence-3\% and steps followed to write-5\%. Thus, it was given for selected students in the schools on separate sheet. After the papers were collected, they were checked by the assistants and re-checked by the researcher to know whether the students followed the steps found in process approach while writing the texts. Moreover, both teachers and students were given questionnaire based on principles of teaching and learning writing skills. The students' questionnaire was translated into Amharic, an official language in Ethiopia, so that it helped me to gain valuable information from them. The questionnaires were piloted out and administered to the teachers and students and returned back to the researcher after being filled by the students and teachers. Classroom observation was also one of the first hand data collecting instruments next to written-test for this study. To have background information about the student's ability through process approach, classroom observation was carried out. The classrooms were observed for three times by the researcher using standardized observation checklist to see student's written works. It enabled the researcher to examine the problem clearly and precisely. Moreover, it was an important tool for the researcher to collect the first hand data by observing directly from the actual teaching-learning process with the target groups. It was observed while the regular English teachers were teaching writing skills.

In order to check the implementation of process approach in teaching writing skills, Grade 12 students' textbooks and teachers' guides were analyzed based on checklist according to principles and theories of teaching writing.

\section{Procedures for data collection}

At the beginning, written-test was prepared and administered in the second semester of 2018 while the students were learning in the actual class. The researcher requested the regular English teacher one class and administered the test. The written test was administered without detailed explanation by announcing its purpose and papers were collected back and checked by the researcher.

Second, questionnaire was administered for the teacher and students so as to get information which can't be seen with naked eyes such as attitude, motivation, self concepts, background information...etc.

Next, classroom observation was carried out to find out the actual problems in writing. The researcher observed the class as non-participant observer on writing lessons. Then, it was followed by content analysis on textbooks and teachers guide of the grade levels.

\section{Procedures for data analysis}

Once, the written-test was marked, the researcher used two means to determine students' writing ability. Then, the scores were analyzed. The raw scores were classified into three levels: high, middle and low. Then, the mean was calculated and compared with in the students' achievement scores. Next to this, the derivation of each score from the mean was calculated. Finally, frequency and distribution were counted between intervals. 
In second place, close-ended questions of the questionnaire was analyzed in tabular method using percentages and frequencies and description in paragraphs for open-ended questions of students and the questionnaire of the teacher as a whole.

Third, classroom observation data were analyzed in tabular form using the criteria on the observation checklist through percentage and frequency.

Finally, content analysis data were analyzed in thematic approach.

\section{Procedures of marking for written-test}

Once the written-test was conducted, the researcher made the marking of the papers in which the researcher engaged himself in rating process. The researcher marked the written-test using his drafts (steps) in the process approach and his background knowledge of the three basic features of a good paragraph: unity, coherence and adequate development and the elements of composition: content, vocabulary selection, grammar, mechanics and organization. They were re-checked by assistants.

\section{Results and Discussions}

\section{Students' written test analysis}

First of all, written test was given for the students to know the performance of them. The result of the test is as follows: This table clearly shows that the students' performance is very poor in writing skill because most of the students (74\%) scored below the average value in the achievement test.

$\mathrm{Z}$ score of the students result also shows that the students were very poor in writing skill because the higher value lies in negative standard deviation and mean or because they perform poor in the test. The results of the students written test illustrates that they need to work hard in writing skill.

This table depicts that the students have lower value in their written test even though there is a missing value. This clearly demonstrates that the students need more practice in writing skill in order to master it.
This histogram also indicates that most of the students score below the average mark in the written test. More than half of the students lie between 1and -1 .

The frequency of the students result shows that the students of Sodo preparatory schools were poor in writing skill because most of the students score below 7.5 out of 20 especially between 2.5 to 7.5 and few students score above the average mark during the written test.

\section{Analysis of students' questionnaire}

As it can be seen from table 1, $255(85 \%)$ of the students preferred process approach and $45(15 \%)$ of the students responded that process approach was better for them. From this, it can be concluded that process approach is preferable to learn writing skill.

From this table, it is possible to see that the students don't learn writing skill usually. 98 (32.6\%) replied that they learn the skill sometimes, $40(13.4 \%)$ said that they learn it rarely and $162(54 \%)$ students replied that they were not learning writing skill at all. Generally, the students were passive in writing skill because they were not exposed to writing exercises.

This table vividly illustrates the students' interest to learn writing skill. $75(25 \%)$ of the respondents responded that they were voluntary to learn but $225(75 \%)$ of the students replied that they were not voluntary to learn writing skill. From this, it can be concluded that most students $(75 \%)$ were not voluntary to learn writing skill. So, they were not good at composing since they dislike or hate the skill.

As the above table shows, 7 (2.3\%) students usually practice writing skill outside the class. 56 (18.7\%) students answered that they practice writing skill sometimes and 20 (6.7) rarely practice writing outside the class.

However, nearly 217 (72.3\%) students said that they were unluckily to practice writing except the classroom. This implied that most students have problems in writing tasks because they were not exposed to practice outside the classroom by themselves. If they practice more writing activities at home, they may become active writers in the class. 
As it is observed from the above table, 34 (11.3\%) have great interest to write a unified paragraph or composition. On the other hand, 69 (23\%) have some interest and 197 (65.7\%) have lesser interest for writing.
This implied that most students have no interest to write, due to this, they lack the ability to express their idea through writing.

\section{Achievement test score}

\begin{tabular}{|c|c|c|c|c|c|}
\hline & & $\begin{array}{l}\text { Frequenc } \\
\mathrm{y}\end{array}$ & Percent & \begin{tabular}{|l} 
Valid \\
Percent
\end{tabular} & $\begin{array}{l}\text { Cumulative } \\
\text { Percent }\end{array}$ \\
\hline \multirow{13}{*}{ Valid } & 4.00 & 45 & 22.5 & 22.6 & 22.6 \\
\hline & 5.00 & 43 & 21.5 & 21.6 & 44.2 \\
\hline & 6.00 & 27 & 13.5 & 13.6 & 57.8 \\
\hline & 7.00 & 29 & 14.5 & 14.6 & 72.4 \\
\hline & 8.00 & 16 & 8.0 & 8.0 & 80.4 \\
\hline & 9.00 & 15 & 7.5 & 7.5 & 87.9 \\
\hline & 10.00 & 5 & 2.5 & 2.5 & 90.5 \\
\hline & 11.00 & 4 & 2.0 & 2.0 & 92.5 \\
\hline & 12.00 & 4 & 2.0 & 2.0 & 94.5 \\
\hline & 13.00 & 3 & 1.5 & 1.5 & 96.0 \\
\hline & 14.00 & 5 & 2.5 & 2.5 & 98.5 \\
\hline & 15.00 & 3 & 1.5 & 1.5 & 100.0 \\
\hline & Total & 199 & 99.5 & 100.0 & \\
\hline Missing & System & 1 & & & \\
\hline Total & & 200 & 100.0 & & \\
\hline
\end{tabular}

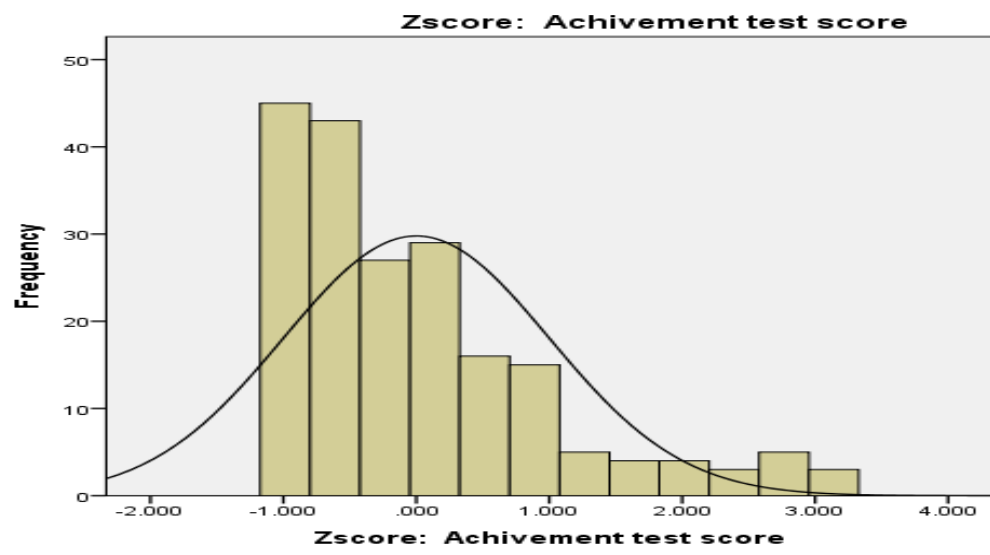

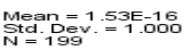

Table.1 Students responses regarding writing approaches

\begin{tabular}{|l|l|l|l|}
\hline \multirow{2}{*}{ Item } & Responses & \multicolumn{2}{|l|}{ Respondents } \\
\cline { 3 - 4 } & & Frequency & Percentages (\%) \\
\hline Which of the following \\
$\begin{array}{l}\text { approach is better for you to } \\
\text { learn writing skill? }\end{array}$ & Process approach & 255 & 85 \\
\cline { 3 - 4 } & Product approach & 45 & 15 \\
\hline Total & & & \\
\hline
\end{tabular}




\section{Z score: Achievement test score}

\begin{tabular}{|cc|c|c|c|c|}
\hline & Frequency & Percent & Valid Percent & $\begin{array}{c}\text { Cumulative } \\
\text { Percent }\end{array}$ \\
\hline-.986 & 45 & 22.5 & 22.6 & 22.6 \\
-.611 & 43 & 21.5 & 21.6 & 44.2 \\
-.236 & 27 & 13.5 & 13.6 & 57.8 \\
.140 & 29 & 14.5 & 14.6 & 72.4 \\
.515 & 16 & 8.0 & 8.0 & 80.4 \\
.890 & 15 & 7.5 & 7.5 & 87.9 \\
1.265 & 5 & 2.5 & 2.5 & 90.5 \\
Valid & 5.640 & 4 & 2.0 & 2.0 & 92.5 \\
2.016 & 4 & 2.0 & 2.0 & 94.5 \\
2.391 & 3 & 1.5 & 1.5 & 96.0 \\
2.766 & 5 & 2.5 & 2.5 & 98.5 \\
3.141 & 3 & 1.5 & 1.5 & 100.0 \\
Total & 199 & 99.5 & 100.0 & \\
Missing System & 1 & .5 & & \\
Total & 200 & 100.0 & & \\
\hline
\end{tabular}

Table.2 Students' response on the frequency they learn writing skill

\begin{tabular}{|l|l|l|l|}
\hline Item & Responses & Respondents \\
\cline { 3 - 4 } & & Frequency & Percentages (\%) \\
\hline How often do you learn & Usually & - & - \\
\cline { 2 - 4 } $\begin{array}{l}\text { writing skill in the } \\
\text { classroom using process } \\
\text { approach? }\end{array}$ & Sometimes & 98 & 32.6 \\
\cline { 2 - 4 } & Rarely & 40 & 13.4 \\
\cline { 2 - 4 } & Not at all & 162 & 54 \\
\hline Total & & 300 & 100 \\
\hline
\end{tabular}

Table.3 Students Response on their Interest to Write Paragraph using Process Approach

\begin{tabular}{|l|l|l|l|}
\hline \multirow{2}{*}{ Item } & Responses & \multicolumn{2}{|l|}{ Respondents } \\
\cline { 3 - 4 } & & Frequency & Percentages (\%) \\
\hline $\begin{array}{l}\text { Are you voluntary to write a } \\
\text { paragraph/composition using } \\
\text { process approach? }\end{array}$ & Yes & 75 & 25 \\
\cline { 2 - 4 } & No & 225 & 75 \\
\hline Total & & 300 & 100 \\
\hline
\end{tabular}

Table.4 Students' responses on the frequency they practice writing outside the class

\begin{tabular}{|l|l|l|l|}
\hline Item & Responses & Respondents \\
\cline { 3 - 4 } & & Frequency & Percentages (\%) \\
\hline How often do you practice & Usually & 7 & 2.3 \\
\cline { 2 - 4 } $\begin{array}{l}\text { writing skill outside the } \\
\text { classroom with process } \\
\text { approach? }\end{array}$ & Sometimes & 56 & 18.7 \\
\cline { 2 - 4 } & Rarely & 20 & 6.7 \\
\cline { 2 - 4 } Total & Not at all & 217 & 72.3 \\
\hline
\end{tabular}


Table.5 Students' Responses to what Extent they are Interested to Write a Paragraph or essay

\begin{tabular}{|l|l|l|l|}
\hline \multirow{2}{*}{ Item } & Responses & \multicolumn{2}{|l|}{ Respondents } \\
\cline { 3 - 4 } & & Frequency & Percentages (\%) \\
\hline To what extent you are & To great extent & 34 & 11.3 \\
\cline { 2 - 4 } $\begin{array}{l}\text { interested in writing a } \\
\text { unified and coherent } \\
\text { paragraph or composition? }\end{array}$ & To some extent & 69 & 23 \\
\cline { 2 - 4 } Total & To lesser extent & 197 & 65.7 \\
\hline
\end{tabular}

Table.6 Teachers response on approaches of teaching writing

\begin{tabular}{|l|l|l|l|}
\hline \multirow{2}{*}{ Item } & Responses & \multicolumn{2}{|l|}{ Respondents } \\
\cline { 3 - 4 } & & Frequency & Percentages (\%) \\
\hline \multirow{2}{*}{$\begin{array}{l}\text { Which approach of teaching } \\
\text { writing skill is better for you? }\end{array}$} & Process approach & 8 & 80 \\
\cline { 2 - 4 } & Product approach & 2 & 20 \\
\hline Total & & 10 & 100 \\
\hline
\end{tabular}

Table.7 Teachers response on encouraging students while using process approach

\begin{tabular}{|l|l|l|l|}
\hline Item & Responses & Respondents \\
\cline { 3 - 4 } & & Frequency & Percentages (\%) \\
\hline \multirow{2}{*}{$\begin{array}{l}\text { How often do you learn writing } \\
\text { skill in the classroom using } \\
\text { process approach? }\end{array}$} & Usually & - & - \\
\cline { 2 - 4 } & Sometimes & 9 & 90 \\
\cline { 2 - 4 } & Rarely & - & - \\
\cline { 2 - 4 } & Not at all & 1 & 10 \\
\hline Total & & 10 & 100 \\
\hline
\end{tabular}

Table.8 Teachers response on giving opportunity to write a paragraph in the class

\begin{tabular}{|l|l|l|l|}
\hline Item & Responses & Respondents \\
\cline { 3 - 4 } & & Frequency & Percentages (\%) \\
\hline How often do you give the & Usually & - & - \\
\cline { 2 - 4 } $\begin{array}{l}\text { opportunity to your students to write } \\
\text { a paragraph/composition in the class } \\
\text { using process approach? }\end{array}$ & Sometimes & 4 & 40 \\
\cline { 2 - 4 } & Rarely & - & - \\
\hline Total & Not at all & 6 & 60 \\
\hline
\end{tabular}

Table.9 Teachers Response on Giving Equal Attention to Writing Skill

\begin{tabular}{|l|l|l|l|}
\hline Item & Responses & Respondents \\
\cline { 3 - 4 } & & Frequency & Percentages (\%) \\
\hline \multirow{2}{*}{$\begin{array}{l}\text { You teach writing skill by giving equal } \\
\text { attention to other skills. }\end{array}$} & Strongly agree & - & - \\
\cline { 2 - 4 } & Agree & - & - \\
\cline { 2 - 4 } & Neutral & - & - \\
\cline { 2 - 4 } & Disagree & 7 & 70 \\
\cline { 2 - 4 } & Strongly disagree & 3 & 30 \\
\hline Total & & 10 & 100 \\
\hline
\end{tabular}


Table.10 Teachers Response on the Type of Writing they Taught

\begin{tabular}{|l|l|l|l|}
\hline Item & Responses & Respondents \\
\cline { 3 - 4 } & & Frequency & Percentages (\%) \\
\hline What type of writing do you make your & Controlled & 7 & 70 \\
\cline { 2 - 4 } students practice in the classroom? & Guided & 2 & 20 \\
\cline { 2 - 4 } & Free & 1 & 10 \\
\hline Total & & 10 & 100 \\
\hline
\end{tabular}

6.5.1. Observation on students' behavior

\begin{tabular}{|c|c|c|c|}
\hline \multirow{2}{*}{$\begin{array}{l}\text { Item } \\
\text { The students: }\end{array}$} & \multirow{2}{*}{$\begin{array}{l}\text { Response } \\
\text { S }\end{array}$} & \multicolumn{2}{|c|}{ Respondents } \\
\hline & & $\begin{array}{l}\text { Frequenc } \\
\mathbf{y}\end{array}$ & $\begin{array}{l}\text { Percentag } \\
\text { e \% }\end{array}$ \\
\hline \multirow[t]{2}{*}{ write a composition using process approach } & Yes & 2 & 16.7 \\
\hline & No & 10 & 83.3 \\
\hline \multirow[t]{2}{*}{ have background experience in writing exercise } & Yes & 3 & 25 \\
\hline & No & 9 & 75 \\
\hline \multirow{2}{*}{$\begin{array}{l}\text { have awareness in using cohesive devices (conditioning } \\
\text { conjunctions) }\end{array}$} & Yes & - & - \\
\hline & No & 12 & 100 \\
\hline \multirow[t]{2}{*}{ have adequate vocabulary } & Yes & 4 & 33.3 \\
\hline & No & 8 & 66.7 \\
\hline \multirow[t]{2}{*}{ make grammatical mistakes } & Yes & 6 & 50 \\
\hline & No & 6 & 50 \\
\hline \multirow[t]{2}{*}{ give feedback in pairs and groups } & Yes & - & - \\
\hline & No & 12 & 100 \\
\hline \multirow[t]{2}{*}{ write coherent and unified paragraph using process approach } & Yes & - & - \\
\hline & No & 12 & 100 \\
\hline \multirow[t]{2}{*}{ take feedback and make certain correction } & Yes & 12 & 100 \\
\hline & No & - & - \\
\hline
\end{tabular}

6.5.2. Teachers Observation Results

\begin{tabular}{|l|l|l|l|}
\hline \multirow{2}{*}{$\begin{array}{l}\text { Item } \\
\text { Teachers: }\end{array}$} & Responses & \multicolumn{2}{|l|}{ Respondents } \\
\cline { 2 - 4 } & & Frequency & Percentage $\%$ \\
\hline \multirow{2}{*}{ encourage students to write paragraph using process approach } & Yes & - & - \\
\cline { 2 - 4 } & No & 12 & 100 \\
\hline \multirow{2}{*}{ show the steps found in process approach } & Yes & 2 & 16.7 \\
\cline { 2 - 4 } & No & 10 & 83.3 \\
\hline \multirow{2}{*}{ give clear instruction for the lesson } & Yes & 4 & 33.3 \\
\cline { 2 - 4 } & No & 8 & 66.7 \\
\hline \multirow{2}{*}{ give enough time for student to write } & Yes & 4 & 33.3 \\
\cline { 2 - 4 } & No & 8 & 66.7 \\
\hline \multirow{2}{*}{ make the students to participate in pairs and groups } & Yes & 1 & 8.3 \\
\cline { 2 - 4 } & No & 11 & 91.7 \\
\hline \multirow{2}{*}{ give feedback on the students' written work } & Yes & 2 & 16.7 \\
\cline { 2 - 4 } & No & 10 & 83.3 \\
\hline \multirow{2}{*}{ motivate learners to use process approach } & Yes & - & - \\
\cline { 2 - 3 } & No & 12 & 100 \\
\hline bring authentic materials for learners in classroom & Yes & - & - \\
\cline { 2 - 3 } & No & 12 & 100 \\
\hline
\end{tabular}


Analysis of open-ended students' questionnaire was also carried out to get find a synergetic effect of triangulated data from all question items. In this way, an open-ended questionnaire item reads "Rank the language skills/areas in order you are interested to learn from one to five (15)- writing, listening, grammar, reading and speaking." In this regard, most students 214 (71.3\%) put them in the following order; grammar, reading, listening, speaking and writing and about $86(28.7 \%)$ put in the order as reading _ grammar _ listening _ speaking and writing. From this, it is possible to generalize that most students have no interest to writing skill instead they were interested on grammar and reading.

Another open-ended questionnaire item reads "List some of the problems that you face while writing a paragraph or composition using process approach." And the students listed out the following as major problems

_ high number of students in the class

_ the time given was not enough

_ lack of vocabulary

_ lack of developing idea if the topic was not clear

- grammar problems and lack of experience from the earlier grades.

From the students' responses, it can be argued that the students were not good at writing/composing because there were different factors that hinder writing activity using process approach.

Students claimed in various ways for the item that reads "what are your suggestions to solve the problem of your writing skill?" The students forwarded the following possible solutions to improve the problems that hinder writing skill.

- The School should build extra classes and library for the students

_ The teacher should show the way how to write a good paragraph or composition

_ The teacher should encourage or motivate us to write

- The teacher should give opportunities to write different paragraphs and

_ The time or period should be extended to one hour.

\section{Analysis of tteachers' rresponses on questionnaire}

The researcher gave questionnaire to ten English teachers of preparatory level. Consequently, they replied as they were asked. They were found between the ages intervals of 28-45 and had Bachelor of Education degree holders in English and 10-23 years experiences. Their responses to close-ended questionnaire were presented as follows;

From this table, it is possible to see that $8(80 \%)$ teachers selected process approach and $2(20 \%)$ chose product approach to teach writing skill. Based on the teachers' response, process approach is better than product approach for them.

According to the above table, 9 (90\%) teachers sometimes encourage their students to write a paragraph using process approach and 1(10\%) teacher was not encouraging them.

As a result, the researchers concluded that the students had no interest to learn writing skill because their teachers sometime encourage them to learn it. However, different scholars suggested that motivation has important role in learning. For example, Brown (1994:6) stated that motivated students have positive attitude towards learning. So, every teacher must encourage his/her students to learn with great interest. The students must be always encouraged to look critically at what they write and taught to draft, correct and re-write.

As per this table, $4(40 \%)$ teachers replied that they sometimes give the opportunity to write a paragraph/ composition to his students and $6(60 \%)$ teachers were not giving the opportunity to write paragraph using process approach. Therefore, the researcher reached at a decision that the students were passive because they lacked the opportunity to write a paragraph/composition in the class. As Byrne (1988:26) stated "The learners must be given the opportunity to practice organizing their ideas to form acceptable paragraphs. Unless the learners are given the opportunity to write what they want to write, that will never learn the skill."

From this table, one can easily observe that $7(70 \%)$ teachers disagreed and 3 (30\%) teachers strongly disagreed with giving equal attention to writing skill, that is, they didn't give equal attention for all language skills. This implied that the students were not active writers because their teachers didn't give equal attention for all language skills. That means, he teaches other skills and ignores writing.

From the above table, 7 (70\%) teachers made their students practice controlled writing and $2(20 \%)$ teachers made students to practice guided writing. On the other hand, 1(10\%) teacher was teaching his students free writing. It is possible to deduce that the students were not 
able to write a unified paragraph/composition because they didn't practice free writing which paves the best way to carry out process approach.

\section{Analysis of open-ended questionnaire}

$\rightarrow$ If your answer for question 1 is process approach, why you preferred it?

The teachers responded that they preferred it because students can write a good paragraph/composition after a plenty drafts. Moreover, this approach has flexible nature which allows learners to develop, change and improve their writing at any steps and it gives ample opportunities for students to ensure that their paragraph has the three essential features of a good paragraph; unity, coherence and adequate development. This indicates that process approach is the best approach to teach writing skill.

$\rightarrow$ What are the factors that affect teaching writing skill through process approach?

The factors were the following:

$\checkmark$ Shortage of classes, Lack of audio-visual materials, Lack of textbook, and Lack of interest

$\rightarrow$ What solutions do you suggest to solve the writing problem?

Based on this question, the following possible solutions were suggested by the classroom English teachers:

$>$ The school administration must build extra classes to have qualitative teaching-learning process.

$>$ The Ministry of Education should supply enough students textbooks (English textbooks) for learners so as they can see the sample writings.

$>$ The students must be exposed to different written materials to see the writer's style and techniques. Moreover, they should practice by their own in their homes.

$>$ The students must carry out different writing tasks in their home because the given time is not enough to teach writing skill through process approach.

As the above table depicts, most of the students 10 $(83.3 \%)$ were not using process approach to learn writing skill while $2(16.7 \%)$ were trying to apply it partially. In addition to this, few students 9 (75\%) were not having good background knowledge on writing skill and 3
(25\%) were having good background knowledge. All of the students were not using cohesive devices while writing certain composition that made them to be very poor in their writing. Furthermore, some students were having good vocabulary usage but $8(66.7 \%)$ of them were not good at vocabulary power to write a paragraph/composition.

In addition, half of the students were making grammatical mistakes in common way but half of them were not doing this. Almost all of the students were not giving feedback in pair/group and their paragraphs/composition were not coherent and united that can attract the readers but all of them voluntary to take feedback and make certain correction. The following table shows this.

As it was observed during study time, the teachers were not teaching writing skill according to its principles. For instance, most of them were not encouraging the students to write using process approach and most of them (83.3\%) were not showing the steps in process approach while the students were writing certain text. To add more, most of teachers $(66.7 \%)$ were not giving clear instruction on how to write and the students were not given enough time to have an effective writing.

It was also observed that the students were not engaged actively in pair/group works to make lesson interactive and lifelong and they were not gaining written feedback on what they wrote. Besides this, the students were not motivated to use process approach while writing outside the classroom and all of the teachers were not using authentic materials while teaching the students in the classroom to make the lesson real-life based. Generally, the data from the observation shows that process approach was not applied in preparatory schools of Wolaita zone mostly.

\section{Results of document analysis}

English textbooks of preparatory level were analyzed. The result showed the following:

The textbook has fourteen (14) chapters and each chapter had one writing activity at the end. The writing activities included in the textbook were writing paragraph, writing letter, essay writing and interpreting table and graphs but most of them were controlled and guided which cannot make students express their idea freely. In addition, they don't contain procedures/steps on how to write a text; rather, they simply say think, plan, write and revise. The 
textbooks have also some common writing activities and the input sources are previous textbooks designed by MOE. Most of the activities were directly taken from those books and they were not communicative and not designed in meaningful contexts; as a result, the textbooks were not authentic to be used in the classrooms. Another problem found during this session was that the textbooks were composed of similar writing activities such as paragraph writing, letter writing and summary writing, but preparatory level is a stage where students can master various forms of academic writings though they were restricted to limited writings which were included in the books. Most of the tasks were designed in product approach not process one-they were not as such communicative. In addition, they were not authentic or real-life based and supported by visual aids.

The suggested procedures in the books were not clear which means they don't show what students do in writing skills. Furthermore, they were not interactive that don't encourage pair and group works for the involvements of learners. Besides these, the writing contents listed in the textbooks were not according to the needs of students-they were traditional and unauthentic. Another most crucial problem was that most of the writing activities in the textbook were not designed according to the level and interest of learners. So, need analysis should be conducted to incorporate the needs of students for writing activities.

In general, the textbooks are not effective and welldesigned in order to teach writing skill because it was not designed to make students interactive and engaged. The textbooks should be revised so that students can have an exposure to practice writing skill activities in the classroom and outside the class and they should contain authentic materials. They should also contain various types of writing activities based on needs of learners.

\section{Conclusions}

In this descriptive study, three specific research questions were asked: 1) How do teachers and students in the school apply process approach in teaching writing skill? 2) What are the major challenges involved in teaching and learning writing skills though process approach? And To what extent do the challenges affect the effectiveness of the approach? In line with these questions, two techniques of data gathering were devised. In other words, in order to achieve these objectives, data were gathered from English teachers and grade-12 students using written test, observation, questionnaire, semi-structured interview and textbook analysis were subjected to both quantitative and qualitative analysis as presented in the methodology section of this paper. The major findings using these techniques are reported below. In order to see if the students' writing reflects the teachers' expectations in the implementation of process approach, teachers were asked to judge their students' success and problems both in questionnaire and in the written test sessions. Students were generally found less successful in meeting the writing requirements and expectations of the teachers, specifically, teachers' expectations in terms of writing skills and English language proficiency because most of the students scored below an average value and also the higher value lied in negative standard deviation and mean.

So as to find out whether the teachers help their students handle their writing in a process approach, both the teachers and the students were asked. The results showed that, first of all, both the teachers and the students appeared to have different views as to the responsibility of teachers to help students improve their writing skills. However, as a whole it was found out that the teachers in the Wolaita Sodo Preparatory school appeared to have paid little attention to help their students improve their writing skills though it is possible that some teachers may individually help their students.

Moreover, pre- and post-tests were given to the participants and the writer has found that students couldn't keep the given good paragraph writing criteria. In effect, students wrote fragmented ideas without giving a complete idea. This point indicates that much has to be done on the students' writing skills. The writer's observation in the real classroom practice also indicated that some students even couldn't write a single meaningful sentence let alone writing effective paragraph. A single sentence contains word, phrase, clause, and other structural and functional categories, but students didn't try to keep all these parameters. Sentences are full of faults and fragmented and the students were found poor in writing skills and most of them were scoring below the average value; The teachers and students of the grade level were not practicing writing skill using process approach-they were not following the stages in process approach; some factors which hinder the implementation of process approach reported by both teachers and students were shortage of time, low background knowledge in writing, and interest, inappropriate contents and lack of support. By and large, the students written test score showed students' 
performance very poor; the students' questionnaire results also showed that they learn writing in rare cases; students were found passive in learning writing skills except few students who were found voluntary and motivated though about 225 (75\%), out of the total students, were not ok, and students' motivation to write outside the class was also reported to be low. According to the students' text book analysis, it was reported that writing exercises found in grade- 12 textbooks were not authentic, and as a result, do not show various steps to develop the students' writing skills, but similar activities were presented in each unit though students at this level must see various forms of academic writings. Therefore, the writers forwarded the following recommendations:

- Students should be given very practical process writing tasks from the very beginning so that they can be able to develop their writing skills step by step.

- Writing tasks should be given individually in order to minimize the dependence on a single student.

- Timely feed backs should be given on written tasks to develop students' confidence on writing, and to develop students' writing through process approach.

\section{References}

Abebe Mengesha (2004). Awareness of Subject Area Instructors about Their Contributions to the Development of Students' Writing Skills. AA: AAUP (Unpublished thesis).

Berlin, J. A. (1988). "Rhetoric and Ideology in the Writing class." College English. (50). (1987). Rhetoric and Reality: Writing Instruction In American Colleges1900 1985.Carbondale: Southern Illinois Press. (1982). "Contemporary Composition: The Major Pedagogical Theories." College English. (44).

Bizzel, P. (1982)."College Composition: Initiation into the Academic Discourse Community." Curriculum Inquiry, (67)6.

Brown, H.T. (1994). Teaching by Practice: An Interactive Approach to Language Pedagogy $\left(4^{\text {th }}\right.$ Ed). London: Longman.

Byrne, D. (1998). Teaching Writing Skills. London: Longman.

\section{How to cite this article:}

Mesfin Mekuria Dangore. 2019. An Assessment on the Implementation of Process Approach in Teaching Writing Skills: The Case of Preparatory Schools in Wolaita Zone. Int.J.Curr.Res.Aca.Rev. 7(4), 28-40.

doi: https://doi.org/10.20546/ijcrar.2019.704.005
Connor, U. (1996). Contrastive Rhetoric: Cross-cultural aspects of Second-language Writing. United Kingdom: Cambridge University Press.

Ede,L. (1992). Work in Progress: A Guide to Writing and Revising. New York: St. Martin's

Flower L, et al. (1990). Exploring a Cognitive and Social Process. New York: OUP.

Harmer, J. (1991). The Practice of English Language Teaching. New York: Longman.

Harmer, J. (2001). The Practice of English Language Teaching. New York: Longman.

Johns, A.M. (1990). L1 Composition theories: Implications for Developing theories of L2. Composition. In B. Kroll(Ed.), Second Language Writing: Research insights for the classroom Cambridge: Cambridge University Press.

Kefelegn Tefera (2003). A Study of Students' Academic Writing in Response to Instructors' Expectations at AAU: Four Departments in Focus-Department Of Foreign Languages and Literature: Addis Ababa: AAU Printing Press.

Kroll, B.M. (1990). What Does time buy? ESL student performance on home versus class composition. In Kroll, B.(E d.), Second Language Writing: Research insights for the classroom. Cambridge. Cambridge University Press.

Mertler, C.A. and Charles, C.M. (2005). Introduction to Educational Research $\left(5^{\text {th }}\right.$ Ed.). New York: Pearson Education, Inc.

Nunan, D. (1998). Language Teaching Methodology: A Test-book for Teachers. New York: Longman.

Pincas, A. (1982). Teaching English Writing. London: Macmillan.

Stern, H.H. (1983). Fundamental Concepts of Language Teaching. Great Britain: OUP.

Teshale Lemma (2009). The Relation between Teachers and Students Perception of Writing Skills and Students Academic Achievement. AA: AAUP (Unpublished thesis)

Ur, P. (1996). A Course in Language Teaching: Practice and Theory. Great Britain: CUP.

Zamel, V. 1983). "The Composing process of Advanced ESL students: Six case studies.” TESOL Quarterly (17). 